\title{
The General Election Results as the Manifestation of Popular Sovereignty
}

\begin{abstract}
Jayus*
*Lecturer, doctor at the Law Faculty of Jember University, in the election law

Abstract

The General Election is closely related to manifestation of popular sovereignty by seeing the results of the elections. This manifestation is the highest value of democracy. In fact, some elections are the result of manifestation of sovereignty if it is legally disputed. The election is a means of democracy that has been chosen among various available options, it becomes a tool for rolling and changing leaders in various positions (President and Vice President, DPR, Provincial DPRD, Regional and other positions). Based on the past elections, there are number of various legal cases concerning the results of the elections which is held every 5 years. In the future, an ideal concept is needed to deal with any disputes over election results to create an atmosphere of democracy that have the value of justice, expediency, and certainty.
\end{abstract}

Keywords: General Election, legally dispute, the concept of general election dispute settlement.

DOI: $10.7176 / J L P G / 93-18$

Publication date: January $31^{\text {st }} 2020$

\section{b. Introduction}

Since the Independence of the Unitary State of the Republic of Indonesia (hereinafter referred to as NKRI) in 1945, the spirit of democracy has emerged with the will to hold General Elections. ${ }^{1}$ This intention was clearly seen by the formation of Act Number 27 of 1948 concerning Elections which was later amended by Act Number 12 of 1949 concerning Elections, but at that time it could not be implemented due to political factors. ${ }^{2}$. The new elections were actually held for the first time in 1955 with the legal basis of Act Number 7 of 1953, which was then held again in 1971 through the Act Number 15 of 1969 and continued as a five-year agenda to elect people's representatives.

Essentially, the election is the activity of electing people or public officials, People's Representative Council (hereinafter referred to as DPR), Regional Representatives Council (hereinafter referred to as DPD), Regional People's Representative Assembly (hereinafter referred to as DPRD), and the President and vice President, or it becomes a means of public control over the future legislations and Presidential position. Whereas the Election of President and Vice President is a general election to elect the President and Vice President in the Unitary State of the Republic of Indonesia based on Pancasila and the 1945 Constitution of the Republic of Indonesia (Article 1 number 1 of Act no. 42 of 2008). In this agenda, the General Election is held by a General Election Commission (hereinafter referred to as KPU), which is national, permanent and independent.

The Election Organizer consists of the General Election Commission and the Election Supervisory Board as an integrated function of the Election Administration to elect members of the DPR, DPD, DPRD, President and Vice President directly by the people ${ }^{3}$. These institutions are guided by the principles of: independent, honest, fair, legal certainty, orderly, public interest, openness, proportionality, professionalism, accountability, efficiency, and effectiveness ${ }^{4}$.

The duties and authority of the KPU in organizing the Election of member of the DPR, DPD and DPRD include:

a. To determine election participants;

b. To establish and announce the results of the recapitulation of the national vote count ...;

c. To issue KPU's decision to legitimate the election results and announce it;

d. To determine and announce the votes obtained to be entitled to any representation in legislature;

e. To announce the elected DPD members ${ }^{5}$.

Furthermore, the duties and authority of the KPU in organizing the Election of President and Vice President include:

a. To determine candidates for President and Vice President who have met the requirements;

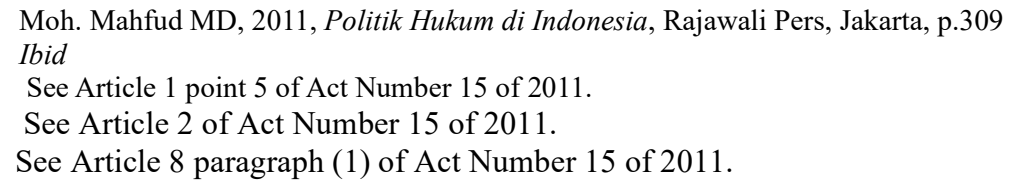


b. To Determine and announce the results of the vote count recapitulation ...;

c. To issue KPU's decision to legitimate the election results and announce it;

d. To announce the elected candidate of President and Vice President and to make the official report ${ }^{1}$.

In its essence, especially before the amendment to the 1945 Constitution of the Unitary State of the Republic of Indonesia (hereinafter referred to as the 1945 Constitution), the regulations for dispute settlement concerning election results is still not available. However, after the amendment to the 1945 Constitution, the regulation concerning the dispute is regulated, and such disputes arise when elections are held directly.

Since the general election is first implemented in 2004, until now, its implementation have always been followed by disputes arising between KPU and the participants, both the political parties or individuals concerning the results of the elections, and even including the Final Voter List (hereinafter referred to as DPT) matter. Regulation of disputes regarding the results of elections has been institutionally accommodated, with the initial concept as regulated in Article III of the Transitional Rules of the 1945 Constitution which states that "the Constitutional Court was formed no later than August 17, 2003 and before it is established, the authority is carried out by the Supreme Court." It is due to the amendment to the 1945 Constitution carried out by the People's Consultative Assembly (hereinafter referred to as the MPR) in a four-time addendum from 1999 to 2002.

The concept of dispute settlement regulation, specifically dispute resolution regarding the election results by the Supreme Court (hereinafter referred to as the MA) until before the establishment of the Constitutional Court (hereinafter referred to as the MK) cannot be implemented, because until its third amendment to 1945 Constitution in 2002, a General Election had never been held. Which means, there has never occurred a dispute regarding the election results.

The concept of the Constitutional Court authority to settle Elections disputes as the first and final court, whose decision is final, basically does not provide other legal remedies opportunities for justice seekers. The concept as the first court is considered inaccurate, because the Constitutional Court is located in the capital city of the country which is far from the electoral district to cover the real situation. Therefore, the first court should be a court that is close to justice seekers, which is able to immediately closely witness the problems related to the implementation of Elections in the electoral district.

Elections is the implementation of popular sovereignty, and popular sovereignty is in the hands of the people. In other words, the Election is the implementation of democracy as the Indonesian choice as mandated in the 1945 Constitution.

Article 1 paragraph (2) of the 1945 Constitution states that Sovereignty is in the hands of the people and is implemented according to the Basic Law. This provision means that the Unitary State of the Republic of Indonesia (hereinafter referred to as NKRI) adheres to the concept of popular sovereignty or democracy. It is also intended to optimize and strengthen the understanding of popular sovereignty adopted by the Indonesian state, because the implementation of popular sovereignty is regulated in the 1945 Constitution ${ }^{2}$. Likewise, if this provision is related to the article 1 paragraph (3) of the 1945 Constitution stating that "The State of Indonesia is a State of law," meaning explicitly affirm that the state ideal is the rule of law. These two provisions show that the state ideals are the democratic state of law and a democratic state based on the constitutional law..

Democracy as the basis of a nation means that the people decides any main issues concerning their lives, including in assessing the policies of the state government, because these policies determine people's lives. Thus a democratic state is a state organized based on the will and power of the people, or it is an organization of the state carried out by the people themselves or with the consent of the people because sovereignty is in the hands of the people ${ }^{3}$.

No matter how good a government is designed, it cannot be considered as democratic, except the officials leading the government are elected by the people in an open and honest way ${ }^{4}$. Elections may vary, but the essence remains the same for all democratic societies ${ }^{5}$.

1 See Article 8 paragraph (2) of Act Number 15 of 2011.

2 Laica Marzuki, 2008, Dari Timur Ke Barat Memandu Hukum, Sekretariat dan Kepaniteraan Mahkamah Konstitusi, Jakarta, p. 65

3 Moh.Mahfud MD, 1993, Demokrasi dan Konstitusi di Indnesia, Studi tentang interaksi Politik dan kehidupan Ketatanegaraan, Liberty, Yogyakarta, p.19.

4 Catur Wido Haruni, 2010,Kajian Kritis Terhadap Penyelesaian Sengketa Pemilihan Kepala Daerah, in Jurnal Konstitusi 3rd Edition, Jakarta, p.28

5 Ibid. 
Election is a democratic mechanism of leaders recruitment, where the people have the right and freedom to choose their candidates. It always becomes a benchmarks to determine a democratic state, although democracy is not solely determined by the existence of elections by the people over their leaders, and it requires some conditions to support the electoral process. These requirements must be taken so that the election truly produces a democratic government leader and is not merely a ritual procession, and these requirements include; the availability of clear and fair rules for all participants, an independent and non-discriminatory organizer, and trust.

Elections as regulated in Article 22E paragraph (1) of the 1945 Constitution states: "Every five years general elections are to be organized in a direct, public, free, secret, honest, and fair way, and in paragraph (2) states: The general elections are organized to elect the members of the DPR, the DPD, the President and the Vice President and the DPRD."

From these provisions it can be interpreted that the election is limited to elect the DPR, DPD, President and Vice President, and DPRD. In the perspective of procedural democracy, the Presidential Election system is a meaningful innovation in the process of consolidating democracy at the national level. Likewise, in a philosophical perspective, the idea of an election for President and Vice President is directly a continuation of a strong desire to improve the quality of democracy.

Election formulation as stipulated in Article 1 number 1 of Act Number 15 of 2011 concerning General Election states: General Election, hereinafter referred to as Pemilu, is a means of implementing popular sovereignty which is held directly, publicly, freely, confidentially, honestly and fairly in the Republic of Indonesia based on Pancasila and the 1945 Constitution of the Republic of Indonesia.

Elections as a means to elect national leaders, through direct elections are expected to produce credible leaders who are supported by the people. The agenda of electing a person or group of people to be a representative in the legislature which is held by upholding the principles as stipulated in Article 1 number 1 of Act No.15 of 2011 is an indicator to assess whether the implementation of the Election has been going well or not ${ }^{1}$. In fact, in practice, violations have occurred over the principles of the Election implementation, both committed by election participants and the organizers.

Violations of General Election can certainly be detrimental to various parties, both for the participants of the Election, as well as the organizers, it will also harm democratic values, law, justice, and the legitimacy of the election $^{2}$, and even lead to disputes over election results which must be accounted for. Besides, the General Election is expected to be an instrument of political change, where the best people can appear, and clean and honest people must be born. Dispute settlement of Elections, particularly criminal acts, is resolved by the general judiciary, while administrative violations are resolved by the KPU and the code of ethics by the Election Supervisory Board, as well as the settlement of disputes over election results by the Constitutional Court.

State policy on the law, including re-conceptualizing judicial disputes over election results, is possible to form new laws or replace old ones as an effort to adjust to the development of community needs. In terms of norms of conduct, there exist a legal norm which only prevail once (einmahlig) and that apply continuously (dauerhaftig) ${ }^{3}$.

The dispute settlement over election results by judicial institutions is an attempt to uphold the law in order to achieve justice. Law enforcement is a process to make legal desires come true. The legal desires are the ideas of the legislature formulated in those legal regulations ${ }^{4}$.

Re-conceptualizing or rearranging the concept of dispute resolution on the election results, is an attempt or an overview of the state in order to find a solution to the problem of handling disputes over election results, i.e., which the judicial institution having the authority to resolve the dispute.

Based on the above legal issues, the problems will be discussed in this study are, first, why the Election results as the manifestation of Popular sovereignty is legally tested, second, the suitable concept of Elections disputes settlement by the Supreme Court.

\section{c. Research Methods}

This study is a normative and doctrinal legal research. Normative is used due to the distinctive character of legal science that lies in the normative method of research ${ }^{5}$. Doctrinal research is used to analyze the principles of law

1 Widodo Ekatjahjana, 2009, Mengagas Peradilan Partai Politik dan Pemilu Dalam Sistem Ketatanegaraan Indonesia, Jurnal Konstitusi PKK FH.Universitas Bengkulu, p.76

2 Ibid.

3 Dasril Radjab, 2009, Politik Hukum Pemilu Di Indonesia, Jurnal Konstitusi P3KP FH.Unjam, Jambi, p. 8

4 Ibid.

5 Peter Mahmud Marzuki, 2009, Penelitian Hukum, Kencana, Jakarta, p. 35 
(civil procedure law), legal literature, expert opinion (doctrine). ${ }^{1}$

This approach is consistent with the view of law as a norm, theorem, and rules that apply in society in accordance with the principles of law. ${ }^{2}$ The analysis method of legal materials is covering legal concepts, legal norms, technical law concepts, law institutions, law figures, law functions and legal sources. ${ }^{3}$

\section{Results and Discussion.}

\subsection{The Elections Results as a Manifestation of Popular sovereignty which is Legally Tested.}

Election is a means of implementing popular sovereignty which is held directly, publicly, freely, confidentially, honestly and fairly in the Unitary State of the Republic of Indonesia based on Pancasila and the 1945 Constitution. It is essentially the activity of electing public officials to be the representatives of the DPR, DPD and DPRD, as well as the President and Vice President. The activity of selecting public officials is actually a process that requires the involvement of many parties, including the participation of the people as the holder of the sovereignty.

The sovereignty of the people, as regulated in the 1945 Constitution, can be found both at the preamble of the 1945 Constitution in the Fourth paragraph ... which shall be built into a sovereign state ..., as well as in Article 1 paragraph (2) of the 1945 Constitution, Sovereignty is in the hands of the people .... ${ }^{4}$.

The 1945 Constitution as the highest law regulates power derived from popular sovereignty into several articles, namely;

1.As stipulated in Article 2 paragraph (1) of the 1945 Constitution stated that, The MPR shall consist of the members of the DPR and the members of the DPD who have been elected through general elections...

2.Article 6A paragraph (1) of the 1945 Constitution, stating that The President and Vice-President shall be elected as a pair directly by the people.

3.As stipulated in Article 19 paragraph (1) of the 1945 Constitution, stating that Members of the DPR shall be elected through a general election.

4.As stipulated in Article 22 paragraph (1) of the 1945 Constitution stating that The members of the DPD shall be elected from every province through a general election.

5.As stipulated in Article 22E paragraph (1) of the 1945 Constitution, stating that General elections shall be conducted in a direct, general, free, secret, honest, and fair manner once every five years. (2) General elections shall be conducted to elect the members of the DPR, DPD, the President and Vice-President, and the Regional People's Representative Council (Dewan Perwakilan Rakyat Daerah or DPRD). (3) The participants in the general election for the election of the members of the DPR and the members of the DPRDs are political parties. (4) The participants in the general election for the election of the members of the DPD are individuals.

The above provisions are norms which functioned to not only providing constitutional rights to the subjects, but also giving restrictions ${ }^{5}$. These restrictions are in line with the 1945 Constitution, that popular sovereignty is carried out according to the Constitution, which means that the Constitution has made restrictions on the implementation of popular sovereignty. These restrictions are also reflected in the stipulation that elections are held every five years, the Election participants to elect DPR and DPRD members are political parties, and to elect DPD members are individuals ${ }^{6}$.

Elections as determined in Article 22E paragraph (1) of the 1945 Constitution states that "General elections shall be conducted in a direct, general, free, secret, honest, and fair manner once every five years," meaning that the six principles are the principles of Election in Indonesia. Jimly Asshiddiqie argued that the principles of $L U B E R$ (Direct, General, Free, Confidential) and JURDIL (Honest and Fair) were separated based on their validity. $L U B E R$ concerns the objective nature that applies in the process of implementing an election or regarding to the election mechanism. Thus, LUBER relates to someone right in determining his choice. Whereas JURDIL is

1 Ibid

2 Soetandyo Wignjosoebroto, 1993, Masalah Metodelogi Dalam Penelitian Hukum Sehubungan Dengan Masalah Keragaman Pendekatan Konseptualnya, Makalah pada Metodelogi Penelitian, FH Undip, p. 30.

3 Philipus M. Hadjon, 1994, Pengkajian Ilmu Hukum Dogmatik (Normatif), Makalah, Fakultas Hukum Unair, Surabaya. p. 3-4.

4 See the fourth paragraph of the Preamble of the 1945 Constitution

${ }^{5}$ Harjono, 2009, Transpormasi Demokrasi, Sekretariat dan Kepaniteraan Mahkamah Konstitusi, Jakarta, p.6

6 Ibid, 
related to the subjective nature of election organizers and implementers who are supposed to act honestly and fairly ${ }^{1}$.

Elections are important instruments in a democratic state that adopts a representative system ${ }^{2}$. It serves as a filtering tool for politicians to represent the voice of the people in the legislature. Those who are elected are considered as people or groups who have the ability or obligation to speak and act on behalf of a larger group through political parties ${ }^{3}$. Therefore, the existence of political parties is a necessity in a modern democratic political life. It was intended to activate and mobilize the people, represent certain interests, provide a compromise for opposing opinions, and provide a means of succession of political leadership in a legal and peaceful manner ${ }^{4}$.

Disputes over the determination of vote counting results of national elections by the KPU, conducted by election participants are the will to protect and fight for their constitutional rights, as mandated in Article 1 paragraph (2) of the 1945 Constitution stating that Sovereignty is in the hands of the people and implemented according to the Constitution. The protection and struggle are carried out consciously by seeing, witnessing and feeling that there has been a vote counting of the results of an election that is not in accordance with the calculation of election participants correctly. In other words, the national vote counting results have a major influence on the vote acquisition for participants in the General Election, both political parties and individuals, so that it also affects the vote results of a legislative candidate, as well as the President and Vice President.

As a rule of law, Indonesia upholds a supremacy law, meaning that all activities carried out by the state and its people must be legally accountable. As determined in Article 1 paragraph (3) of the 1945 Constitution states, the Indonesia is a state of law. It means that Indonesia is a democratic rule of law or a democratic state based on law. Therefore, various efforts have been made by the state in the context of disputes settlement over election results due to the determination of the national vote count by the KPU, through various judicial environments, both the general court environment, namely the Supreme Court and its subordinate court environment, as well as the constitutional court environment namely the Constitutional Court in the statutory regulations.

Limitation on popular sovereignty implementation that are manifested in democracy and elections, means that there is no absolute popular sovereignty. Therefore these limitations are not limited to their implementation, but it also involve the implementation process, namely democratic elections. In the perspective of the theory of democracy, an Election by electing candidates for officials or people who want to become members of the DPR, DPD, President and Vice President and DPRD, would be better, because voters know who they want to vote for ${ }^{5}$.

Democracy is not merely limited to the implementation of regular elections, namely the existence of competition between candidates for public officials as mentioned above, and people's participation in assessing and determining their votes, and it is not limited to elections as a means of gaining power in various ways that violate democratic principles, but essentially the General Elections must be able to present substantive or real democracy. Likewise, elections are not limited to implementing procedural democracy, but are also able to realize substantive democracy ${ }^{6}$. Samuel Huntington, as cited by Harjono, in a democratic government, the main democratic procedure for electing leaders and policy makers is through competitive elections by the people. Thus, a political system is considered democratic if most of the policy makers are chosen through fair, honest and periodical elections where the candidates freely compete for votes, and all adult citizens are given the right to vote ${ }^{7}$.

Democracy is not only interpreted as a norm of rules and legal decisions, but more importantly is a conformity with the will and sense of justice of the people ${ }^{8}$. It cannot leave and violate the constitutional rights of citizens, because a democratic state must be based on the law. Democracy truly stands on the principle of recognition of citizenship with all its rights, and its implementation should not violate the rights of the people 9

The democracy adopted is in substance and as value democracy. As a value, democracy is built on three pillars: First, freedom. Democracy must be supported by individual freedom in expressing ideas and creativity, because

1 Jimly Asshiddiqie, 2002, Konsolidasi Naskah UUD 1945 Setelah Perubahan Keempat, Pusat Studi HTN FH.UI, Jakarta, p. 2

2 Kusnardi dan Harmaily Ibrahim, 1983, Pengantar Hukum Tata Negara Indonesia, Jakarta, PSH Tata Negara

FH.UI, Jakarta, p. 328

3 Miriam Budihardjo, 1982, Dasar-dasar Ilmu Politik, Gramedia, Jakarta, p. 175

${ }^{4}$ Ichlasul Amal, 1988, Pengartar, Teori-teori Mutakhir Partai Politik, Tiara Wacana, Yogyakarta, p. xi

5 Harjono, Transpormasi........... Op.cit.

${ }^{6}$ Lihat Laporan Tahunan Mahkamah Konstitusi Republik Indonesia, 2011, Mengawal Demokrasi Menegakan Keadilan Substantif, Jakarta, p. 14

7 Harjono, 2008, Konstitusi Sebagai Rumah Bangsa,Sekretariat Jendral dan Kepaniteraan MKRI, Jakarta, p. 45

8 See the Annual Report of the Constitutional Court, Mengawal Demokrasi...... Op.Cit., p.15

9 Ibid 
it demands freedom of opinion, there will be no censorship of opinions. Second, Pluralism. Freedom needs to be accompanied by an appreciation for difference and respect for diversity. Third, tolerance. Tolerance determines that individuals or communities are in inseparable life. It even gives a place for the minority in democracy. Thus, there is no longer the oppression of the majority against the minorities ${ }^{1}$.

Democracy does not always mean that a leader must be elected directly. When the awareness of democracy has truly grown among the people, there is no problem about that, meaning that there has been spaces for minorities, they are also held by the principle of responsibility and accountability, and it must be adjusted to the objective and subjective situation of the community ${ }^{2}$. Democracy does not always mean that a leader must be elected directly. When the awareness of democracy has truly grown among the people, there is no problem about that, meaning that there has been spaces for minorities, they are also held by the principle of responsibility and accountability, and it must be adjusted to the objective and subjective situation of the community ${ }^{3}$.

Therefore, a mature democracy will no longer rely on power. It will grow as a morality of power, and all kinds of practices of power will submit to moral principles.

Election is and important aspect of democracy to be widely used and implemented with integrity and quality, both in the process and the results. The principles of democratic elections are also clearly implemented and as a means of implementing popular sovereignty which is carried out directly, publicly, freely, confidentially, honestly, and fairly. The practice of democracy in elections which is characterized by money transactions and fraud show how to deal with democracy which is interpreted procedurally.

Essentially, democracy should also consider aspects of ethics and morality ${ }^{4}$. There is an ethical corridor where people can take part in a democratic process, meaning that everyone cannot merely feel free to involve as a politician on behalf of democracy. Democracy must be built through the active role of society. The state is demanded to uphold democracy at the community level through the forces that exist within the community itself, and democracy will never grow by only spreading the state's agents in society ${ }^{5}$.

The formulation of Article 1 paragraph (2) of the 1945 Constitution as mentioned above which states that "Sovereignty is in the hands of the people and is implemented according to the Basic Law", implies a change in the structure of state institutions. Besides that, the provision contains two principles, namely the First principle of popular sovereignty or democracy, which is stated in the sentence of "sovereignty is in the hands of the people". Second, the principle of rule of law or constitutionalism, which is implied in "and is implemented according to the Constitution ${ }^{6}$. The combination of these two principles explains that the implementation of popular sovereignty in the state system must have corridors and limits, because without these limits popular sovereignty can be used arbitrarily ${ }^{7}$.

As previously elaborated, Election is an activity to elect public officials or members of the DPR, DPD, President and Vice President and DPRD, are expected to be able to represent the people's voices represented. Therefore, legislative and executive members elected or formed on the basis of people's choice are not limited to the involvement of citizens in the election, but also accommodate all the desires, needs and aspirations in determining policy.

Provisions in Article 10 paragraph (1) d of Act No. 24 of 2003 as an organic law, basically reaffirms that the Constitutional Court has the authority to decide disputes over election results, as referred to in Article $24 \mathrm{C}$ of the 1945 Constitution. The validity of its legal arrangements can be further known from the provisions in Article 271 paragraph (1) of Act No. 8 of 2012 which states, Election Disputes are disputes between KPU and Election participants on the determination of national election results ${ }^{8}$. And in Article 271 paragraph (2) it states, a dispute over the determination of the vote results nationally as referred to in paragraph (1) is a dispute over the determination of the vote that can affect the allocation of seats of election participants. Therefore as regulated in Article 272 paragraph (1) of Act No. 8 of 2012 states, in regard the dispute that may occur, the participants may submit a request for cancellation of the determination of the vote counting results by the KPU to the Constitutional Court ${ }^{9}$.

\footnotetext{
${ }^{1}$ Harjono, Constitution as......... op cit, p. 46-47

2 Ibid.

3 Ibid.

4 Ibid.

5 Ibid.

6 Ibid.

7 Ibid.

8 Lihat Pasal 258 ayat (1) UU No. 10 Tahun 2008

9 See Article 259 paragraph (1) of Act No.10 of 2008
} 
Disputes may also occur between the KPU and participants of the General Election, candidates for President and Vice President, concerning vote count results that affect the determination of the elected candidate or the determination to be re-elected in the Presidential Elections. Therefore, as stipulated in Article 201 paragraph (1) of Act no. 42 of 2008 stating that Regarding the determination of Presidential Elections Results, any objection can only be submitted by the candidate to the Constitutional Court ${ }^{1}$.........and in Article 201 paragraph (2) it states, the Objection as referred to in paragraph (1) is only the results of the vote count that affect the determination of the election of a candidate or the determination to be re-elected in the presidential elections ${ }^{2}$.

Rule the Majority theory implies the idea of popular sovereignty, namely majority and minority of those who represent the people in the legislature. When sovereignty is carried by the representatives, there exist a common thread that connects to direct sovereignty, i.e., that the people directly elect their representatives candidate ${ }^{3}$.

The Constitutional Court moves from a counting court that only hears disputes over election results between participants and organizers by examining more substantial matters, namely violations and fraud that distort the substance of democracy and actually violate the constitutional rights of citizens, it is not merely the right to vote but also the right for real democracy ${ }^{4}$. As a consequence, the Court does not only decide which vote count is correct or makes its own count, but to command re-election or vote-counting or even re-voting ${ }^{5}$. The impossibility of determining the correct count, if the votes counted were obtained in an incorrect way, it is not only related to manipulation at the election or counting process, but since the preparation of the voter register ${ }^{6}$.

The Constitutional Court, as the pioneer of democracy, is obliged to guarantee that the constitutional rights of citizens will not be violated or manipulated, meaning that no one may prosper from irregularities and violations committed by the organizer, and no one may be harmed by irregularities and violations committed by others (nullus/nemo commodum capere potest de injuria sua proparia) ${ }^{7}$.

Further arrangements of resolving disputes on the results of the General Elections, including the Election of members of the DPR, DPD and DPRD, as well as the Presidential Elections, are stipulated in MK Regulation No. 16/PMK /2009, as well as in Regulation MK No.17/PMK/2009.

\begin{tabular}{|c|c|c|c|}
\hline No & SUBSTANCE & THEORY & RESULTS OF ANALYSIS \\
\hline 1 & $\begin{array}{l}\text { Correlations of Laws and } \\
\text { Politics }\end{array}$ & $\begin{array}{l}\text { The Constitution and } \\
\text { State of Law } \\
\text { - } \quad \text { Democracy and } \\
\text { Elections } \\
\text { - } \quad \text { Type of Law/ Law and } \\
\text { Politics Configuration }\end{array}$ & $\begin{array}{l}\text { Law and Politics are inseparable, } \\
\text { and it is difficult to determine } \\
\text { which one is most influential, and } \\
\text { the law is always weak. }\end{array}$ \\
\hline 2 & $\begin{array}{l}\text { The causes of legal } \\
\text { disputes relating the } \\
\text { Elections results. }\end{array}$ & Idem & $\begin{array}{l}\text { The constitutional rights of the } \\
\text { people harmed by the national } \\
\text { votes results of KPU has an } \\
\text { influence on the seats obtained in } \\
\text { the parliament as well as the } \\
\text { results of the presidential election. }\end{array}$ \\
\hline 3 & $\begin{array}{l}\text { The validity of legal } \\
\text { arguments }\end{array}$ & Idem & $\begin{array}{l}\text { Based on the Articles 24C UUD } \\
1945 \text {, UU No.24 of } 2003 \text {, UU No. } \\
42 \text { of } 2008 \text {, UU No. } 15 \text { of } 2011 \text {, } \\
\text { UU No. } 8 \text { of } 2012 \text {, PMK. } \\
\text { No.16/2009 and } \\
\text { No.17/2009 PMK. }\end{array}$ \\
\hline
\end{tabular}

\footnotetext{
1 See Article 201 paragraph (1) of Act No.42 of 2008

2 See Article 201 paragraph (2) of Act No.42 of 2008

3 Ibid.

${ }^{4}$ Lihat Laporan Tahunan Mahkamah Konstitusi Republik Indonesia, Mengawal Demokrasi...... Op.Cit., p. 15

5 Ibid

6 Ibid

7 Ibid
} 


\subsection{The concept of electoral dispute resolution in the Supreme Court}

The Supreme Court, including the subordinate judicial institutions, as regulated in Article 24 paragraph (2) of the 1945 Constitution is a judicial institution that own judicial authority. The judicial power as regulated in Article 24 paragraph (1) of the 1945 Constitution is an independent power to administer justice to uphold law and justice. It is also regulated in Article 1 of Act No. 48 of 2009 concerning Judicial Power stating that judicial power is the power of an independent state to administer justice in order to uphold law and justice based on Pancasila for the realization of the Republic of Indonesia State of Law.

The power of an independent state means the authority of the judiciary is separated from the authority of the government and the rule of law, and is independent from the influence of the two powers ${ }^{1}$. The politics of law in the area of judicial power is clearly intended to ensure consistency in the realization of an independent, authoritative judicial body that is supported by professional law enforcement officers with integrity ${ }^{2}$. Judges or judicatures must be independent, which means they do not depend or are bound to anyone to decide objective decisions. The independence and freedom of judges are not only desired and expected by every nation, but are the principles in every justice system ${ }^{3}$.

Before the amendment, the Article 24 paragraph (2) of the 1945 Constitution does not state judicial bodies own the judicial authority, but the authority is submitted to the implementing law to regulate them. However, after the amendment to the 1945 Constitution, the formulation of Article 24 paragraph (2) of the 1945 Constitution stipulates the administration of judicial power by the Constitution. The administrators of judicial authority are referred to as follows:

1. A Supreme Court and the subordinate judicial bodies in the general court, religious court, military court, and the state administrative court environment;

2. A Constitutional Court.

The amendment to Article 24 paragraph (2) of the 1945 Constitution impacts on changes in the structure of the constitution, particularly in the judicial power which originally only consisted of the Supreme Court and its subordinate judicial environment, is added by the Constitutional Court as the executor of the new power ${ }^{4}$. As regulated in Article 1 of Act No. 3 of 2009 concerning the Supreme Court, it states that the Supreme Court is one of the subject of judicial power as referred to in the 1945 Constitution.

The authority of the Supreme Court as regulated in Article 24A of the 1945 Constitution includes:

1. To try at the cassation level;

2. To test the statutory regulations under the Act against the law;

3. To Have other authorities granted by law.

By these provisions, the Supreme Court's authority, namely to try at the cassation level and to test the statutory provisions under the law, is the authority attributively given by the Constitution. Whereas, the Constitution govern the law to add new authority, but the law does not elaborate the authorities given to the Supreme Court. 5 . In other words, the 1945 Constitution mandated the Supreme Court by two constitutional authorities, namely (1) trying at the cassation level, and (2) testing the statutory regulations under the law against the law ${ }^{6}$. While other additional authorities are constitutionally delegated to the legislators to determine their own ${ }^{7}$. It means that this additional authority does not include the constitutional authority granted by the Constitution, but is held or nullified only by the law ${ }^{8}$.

The Supreme Court's authority at the cassation level actually arises because under the Supreme Court existed the general court, the religious court, the military court, and the state administrative court environment. The decisions of the four judicial institutions are appealed to the Supreme Court, thus the Supreme Court is the peak of the four judicial environments following it ${ }^{9}$. Jimly Asshiddiqie argued that the Supreme Court was the highest

1 Gayus Lumbuun, 2012, Evaluasi Pengaturan dan Penyelenggaraan Kewenangan Mahkamah Agung Untuk Mewujudkan Peradilan yang Independen, Bersih, Imparsialtas dan Terpercaya di Indonesia, Makalah dalam Simposium Basional, Surabaya, hlm. 2

2 Ibid.

3 Ibid.

4 Harjono, Konstitusi Sebagai .........Loc.Cit, hlm. 134

5 Ibid, 136

${ }^{6}$ Jimly Asshiddiqie, 2006, Perkembangan dan Konsolidasi Lembaga Negara Pasca Reformasi, Sekretariat Jenderal dan Kepaniteraan MKRI, Jakarta. p. 160
7 Ibid,
8 Ibid
9 Harjono, Transpormasi........... Op Cit, p. 137 
judicial authority in the environment of the general court, religious court, state administrative court and military court. This Court is essentially the guardian of Indonesian law ${ }^{1}$.

The authority of the Supreme Court to try the statutory provisions under the law against the law as a consequence that the Supreme Court is the guardian of the law. Thus, the Supreme Court upholds the law through:

1. The sentences on concrete-individual cases tested to avoid violation of law;

2. Trying the statutory provisions under the law against the law.

Another authorities of the Supreme Court which is attributively determined by the 1945 Constitution prior to the formation of the Constitutional Court, is the authority to handle the dispute resolution of the election results as regulated in Article III of the Transitional Rules which states that the Constitutional Court was formed no later than on August 17, 1945 and before its establishment, the authority was established by the Supreme Court.

The authority of the Supreme Court in resolving disputes over the results of the General Election before the formation of the Constitutional Court cannot carried out, because the General Election has not been held and of certainly there has not occurred any dispute regarding the election results. It means although the Constitutional Court is given the authority to settle disputes regarding the results of the General Election, the authority cannot be carried out.

Although Indonesia is a state of law, and the legal norms have been produced, in fact there have been various crimes or violations against the law committed by the people. Ironically, some of the perpetrators are the legislators and officials themselves, who supposed to play important role in reinforcing the law ${ }^{2}$.

Rizal Ramli as cited by Abdul Wahid stated that the legal mafia was increasingly rampant, because the legal mafia were also officials in the attorney general's office, police and judicial institutions. As a result the legal is only incisively applicable to the ordinary people. They can build criminal networks through government, council, judicial and bureaucratic channels, and strategic pillars that are considered to have the capability and loyalty to support the political acceleration of crime ${ }^{3}$.

It is known that the law enforcement in this country is scarce. Harkristuti Harkrisnowo, as cited by Hufron confirmed that the current legal condition in Indonesia is suspected of approaching its nadir, it has become an extraordinary attention both by the domestic and international community. Particularly, the process of law enforcement is seen as discriminatory, inconsistent, and prioritizes the interests of certain groups ${ }^{4}$.

Munir Fuady as cited in Hufron opined six factors that obstruct the implementation of law enforcement by the upholder were as follows: (1) the poor quality of judges, prosecutors, police, and advocates; (2) denial to the principle of the right man in the right place; (3) low commitment for law enforcement; (4) there is no good and modern law enforcement mechanism; (5) the strong influence of political intervention and power into the state institution especially the police, prosecutors and judiciary; (6) the existence of organized crime among members of the institution in the form of judicial mafia ${ }^{5}$. Supporting the above opinion Hikmahanto Juwana, as quoted in Hufron, points out five factors that the law enforcement in Indonesia is difficult to realize: First, law enforcement officials are subject to allegations and accusations of corruption or bribery; Second, the judicial mafia is rife; Third, the law seems to be able to be played, twisted, and even only supports those who have high social status; Fourth, law enforcement is weak and has lost the public trust; Fifth, the apathetic community, to carry street justice processes ${ }^{6}$.

Soerjono Soekanto, as cited in Hufron, proposed five factors that determine the effectiveness of law enforcement, including: (1) providing examples of legal compliance by law enforcement officials; (2) showing direct and strict attitude (zakelijk) of law enforcers; (3) adjusting the applicable regulations with the latest technological developments; (4) socialization regarding the existence of regulations that apply to the community; (5) providing sufficient time for the community to understand the new rules made ${ }^{7}$.

1 Jimly Asshiddiqie, Perkembangan dan Konsolidasi ...... Op Cit, p,159

2 Abdul Wahid, 2012, Membaca Politik Kriminalisasi Mahkamah Konstitusi, Jurnal PKK FH. Unitomo, Surabaya.p.

12

3 Ibid.p. 17

4 Hufron, 2012, Mewujudkan Penegakan hukum yang berwibawa Suatu Pendekatan Sistem, Makalah Seminar Fungsi Pengawasan Komisi Yudisial, Surabaya. p. 1

5 Ibid.

6 Ibid.

7 Ibid. 
Even though the constitution has outlined its status as a rule of law, in fact its implementation is contrary to the constitution and legal norms. The effect of inconsistencies between the norms and reality, the authority of the judiciary is vague ${ }^{1}$.

Masyri Yunto Said as cited in Abdul Wahid, stated that lately the portrait of the judiciary has become the public intention, and public trust in this institution is fading, which has fallen sharply and is experiencing degradation. It happens because the judiciary can no longer show its authority as a sacred institution for people to fight for justice ${ }^{2}$.

The problem of the judiciary is increasingly raised and almost every day is reported in the newspaper. Both national and local media always put their attention to this institution, regarding the legal violations of law enforcement by the lawmakers. The motives are varied, one of which is to fulfill their personal interests and desires to live a luxury life. Ironically, their actions unfortunately harm the image of the judiciary itself ${ }^{3}$.

The Indonesian law has always been public attention. It is caused by its failure to carry its function to protect and provide justice for the people. Some people have cynically assess that the law is in a serious condition, and it even heading to decayn ${ }^{4}$. The law is facing its lowest point that is the loss of the spirit of law, upset and chaotic life of law ${ }^{5}$

According to Kuntowibisono, as quoted in Rachmad Safaat there has been a destruction of the vision and mission of the law that leads to the destruction of the rule of law. This condition means everyone is playing through the law ${ }^{6}$. From such circumstances, there are clearly those who cry, some who laugh, some who sell, who are naked, some who have no shame, and anything in it ${ }^{7}$.

In such condition, the law has no power to organize itself, it is at the point of chaos, and it leads to the occurrence of legal crisis that the lack of public access to justice and a fair and impartial judiciary as their basic rights $^{8}$. Crisis is abnormal, in which various organizations prepared to organize various process in society are not able to carry out their functions properly, and the judiciary has increasingly lost its prestige as an access to obtain justice ${ }^{9}$.

The judiciary is dominated by interests and power, and is no longer in an authoritative position to organize and control, but instead is controlled by that power ${ }^{10}$. As a result, the products of judicial decisions are also experiencing crisis, even it is very difficult to find a judge who wants to examine, try and decide on a case, by listening to the conscience, and to find articles in the regulations to support his decision ${ }^{11}$.

The poor image of the judiciary is also caused by a shift of the judiciary role as an institution which is expected to resolve the case by prioritizing the balance of legal certainty and the value of justice, into an institution which prioritizes the fight for victory ${ }^{12}$. This shift orientation has triggered the arise of judicial mafia practices, and this situation has been aggravated by the performance of law enforcement officials who tend to deny their professional code of ethics, weak internal supervision, and poor quality of professionalism ${ }^{13}$.

Regarding such conditions, it is questioned that what is the law enforced for? Laws are enforced to achieve legal objectives, namely justice (gerechtigkeit), legal certainty (rechtssicherkeit), and expediency (zweckmabigkeit). There are some terms known in justice, namely: procedural justice, legalist justice, commutative justice, distributive justice, vindictive justice, creative justice, substantial justice, and social justice $^{14}$.

The second objectives of law enforcement is the birth of legal certainty. The principles of legal certainty are: (a) principles of legality, constitutional and rule of law; (b) the principle of the law, establishes various sets of regulations regarding the way, the government and its officials, to carry out governmental actions; (c) no

1 Abdul Wahid, 2009, Etika Profesi Hukum (rekontruksi penegakan hukum di Indonesia), Bayu Media, Malang. p.

2 Ibid,

3 Ibid.

${ }^{4}$ Rachmad Safaat, 2011, Advokasi dan Alternatif Penyelesaian Sengketa, Surya Pena Gemilang, Malang, p. 13

5 Ibid

6 Ibid

7 Ibid.

8 Ibid.

9 Ibid.

10 Ibid.

11 Ibid.

12 Ibid.

13 Ibid.

14 Hufron, Mewujudkan Penegakan hukum ......... Cit, p. 5 
retroactive principle, where legislation before binding must be promulgated and announced appropriately; (d) the principle of non-liquet, the judge must not reject the case, due to the unavailability or unclear law; (e) the principles of free, independent, impartial, objective, rational, just and humane justice; (f) human rights must be formulated and guaranteed in the Constitution or the law. The principle of certainty is attached to the principle of equality of treatment. This principle demands the same case to be treated the same, and different cases are treated differently (treat like cases alike and different cases differently) ${ }^{1}$.

While legal expediency means the law is considered good and appropriate, if the existence of the law can provide and guarantee as much happiness as possible for as many people as possible (greatest happiness for greatest number) $)^{2}$.

Law enforcement will be authoritative when the implementation is upheld by law enforcement agencies in a clean, honest, fair, certain and beneficial manner for the community. Realizing law enforcement requires the existence of progressive law enforcement, namely carrying out the law according to the spirit and deeper meaning ${ }^{3}$. In other words, law enforcement is carried out with determination, dedication, empathy, commitment to suffering, and courage to find other than common ways, and to not merely using dogmatic positivism approach that emphasizes mere aspects of formality and procedure ${ }^{4}$, but doing a substantial approach i.e., deeply examine the material and substantial that lives and is felt by the community.

\section{Conclusion}

Based on the result of the research, it can be concluded as follows:

1. The results of the general election are still being legally tested due to violations of its implementation. These violations are related to the KPU's legal issues as the election organizer, one and another participants of the Elections, and any matters that cause the popular sovereignty to be legally tested. Thus, the validity and legality of the Elections results must be absolutely certain and is settled based on applicable laws and regulations.

2. The concept of the Supreme Court to adjudicate disputes over election results can actually occur by looking at the provisions or authorities granted by the Constitution against the Supreme Court, these authorities are other authorities given by the law (attribution authority). disputes over election results is objective, thus the Supreme Court can be an institution that handles / hears concrete events concerning the implementation of Elections for any dispute occurs, but it must be stated clearly and firmly that the attribution authority must be stated in a law.

\section{References}

BOOKS

Harjono, 2008, Konstitusi Sebagai Rumah Bangsa,Sekretariat Jendral dan Kepaniteraan MKRI, Jakarta.

Harjono, 2009, Transpormasi Demokrasi, Sekretariat dan Kepaniteraan Mahkamah Konstitusi, Jakarta.

Ichlasul Amal, 1988, Pengartar, Teori-teori Mutakhir Partai Politik, Tiara Wacana, Yogyakarta.

Jimly Asshiddiqie, 2002, Konsolidasi Naskah UUD 1945 Setelah Perubahan Keempat, Pusat Studi HTN FH.UI, Jakarta.

Jimly Asshiddiqie, 2006, Perkembangan dan Konsolidasi Lembaga Negara Pasca Reformasi, Sekretariat Jenderal dan Kepaniteraan MKRI, Jakarta.

Kusnardi dan Harmaily Ibrahim, 1983, Pengantar Hukum Tata Negara Indonesia, Jakarta, PSH Tata Negara FH.UI, Jakarta.

Laica Marzuki, 2008, Dari Timur Ke Barat Memandu Hukum, Sekretariat dan Kepaniteraan Mahkamah Konstitusi, Jakarta.

Laporan Tahunan Mahkamah Konstitusi Republik Indonesia, 2011, Mengawal Demokrasi Menegakan Keadilan Substantif, Jakarta.

$\begin{array}{ll}1 & \text { Ibid. } \\ 2 & \text { Ibid. } \\ 3 & \text { Ibid. } \\ 4 & \text { Ibid. }\end{array}$ 
Liliana Tedjosaputro, 2003, Etika Profesi dan Profesi Hukum, Aneka Ilmu, Semarang.

Miriam Budihardjo, 1982, Dasar-dasar Ilmu Politik, Gramedia, Jakarta.

Moh. Mahfud MD, 2011, Politik Hukum di Indonesia, Rajawali Pers, Jakarta.

Moh.Mahfud MD, 1993, Demokrasi dan Konstitusi di Indnesia, Studi tentang interaksi Politik dan kehidupan Ketatanegaraan, Liberty, Yogyakarta.

Peter Mahmud Marzuki, 2009, Penelitian Hukum, Kencana, Jakarta.

\section{Journals and Papers}

Catur Wido Haruni, 2010, Kajian Kritis Terhadap Penyelesaian Sengketa Pemilihan Kepala Daerah, in Jurnal Konstitusi 3rd Edition, Jakarta.

Abdul Wahid, 2012, Membaca Politik Kriminalisasi Mahkamah Konstitusi, Jurnal PKK FH. Unitomo, Surabaya.

Hufron, 2012, Mewujudkan Penegakan hukum yang berwibawa Suatu Pendekatan Sistem, Makalah Seminar Fungsi Pengawasan Komisi Yudisial, Surabaya.

Widodo Ekatjahjana, 2009, Mengagas Peradilan Partai Politik dan Pemilu Dalam Sistem Ketatanegaraan Indonesia, Jurnal Konstitusi PKK FH.Universitas Bengkulu.

Dasril Radjab, 2009, Politik Hukum Pemilu Di Indonesia, Jurnal Konstitusi P3KP FH.Unjam, Jambi.

Philipus M. Hadjon, 1994, Pengkajian Ilmu Hukum Dogmatik (Normatif), Makalah, Fakultas Hukum Unair, Surabaya.

Soetandyo Wignjosoebroto, 1993, Masalah Metodelogi Dalam Penelitian Hukum Sehubungan Dengan Masalah Keragaman Pendekatan Konseptualnya, Makalah pada Metodelogi Penelitian, FH Undip.

Gayus Lumbuun, 2012, Evaluasi Pengaturan dan Penyelenggaraan Kewenangan Mahkamah Agung Untuk Mewujudkan Peradilan yang Independen, Bersih, Imparsialtas dan Terpercaya di Indonesia, Makalah dalam Simposium Basional, Surabaya.

\section{Legislations}

Constitutional Court Regulation Number: 16 / PMK / 2009 concerning Guidelines for Official Reports in Dispute over Election Results.

Constitutional Court Regulation Number: 17 / PMK / 2009 concerning Procedures for Filing Objection of the Determination of the Election Results of the President and Vice President.

The 1945 Constitution of the Republic of Indonesia;

The Act Number 24 of 2003 concerning the Constitutional Court;

The Act Number 42 of 2008 concerning General Elections of President and Vice President;

The Act Number 27 of 2009 concerning the People's Consultative Assembly, the People's Representative Council, the Regional Representative Council and the Regional People's Representative Council.

The Act Number 48 of 2009, concerning Judicial Power.

The Act Number 15 of 2011 concerning General Election Organizers.

The Act Number 8 of 2012, concerning General Elections of members of the People's Legislative Assembly, the Regional Representative Council and the Regional People's Representative Council; 